\title{
Pengembangan Soal Statistika Model PISA untuk Melatih Kemampuan Literasi Statistika Siswa
}

\author{
Nielda Junika ${ }^{1}$, Nur Izzati², dan Linda Rosmery Tambunan ${ }^{3}$ \\ $1^{*}, 2,3$ Program Studi Pendidikan Matematika, Universitas Maritim Raja Ali Haji \\ Jalan Politeknik Senggarang PO. BOX 155, Tanjungpinang, Kepulauan Riau, Indonesia \\ 1*nieldajunika97@gmail.com, 2nurizzati@umrah.ac.id,3tambunanlinda66@gmail.com
}

Artikel diterima: 06-11-2019, direvisi: 26-09-2020, diterbitkan: 30-09-2020

\begin{abstract}
Abstrak
Pencapaian prestasi matematika siswa di Indonesia masih rendah, terlihat dari hasil studi PISA pada tahun 2015. Salah satu faktornya dikarenakan siswa kurang terlatih menyelesaikan soal berkarakteristik seperti soal PISA. Dibutuhkan suatu pengembangan soal yang mampu memberi ruang pada siswa untuk melatih kemampuan literasi matematis yang salah satunya yaitu kemampuan literasi statistika. Tujuan penelitian ini adalah mengembangkan soal statistika model PISA yang berkualitas untuk melatih kemampuan literasi statistika siswa. Jenis penelitian yang digunakan yaitu Research and Development dengan Model 4D (Four D). Subjek uji coba penelitian ini adalah siswa kelas VIII (8) B SMP Negeri 1 Bintan tahun pelajaran 2018/2019. Instrumen pengumpulan data yang digunakan yaitu instrumen untuk mengukur kevalidan soal dan lembar hasil uji coba. Teknik analisis data yang digunakan yaitu analisis data hasil validasi soal dan hasil uji coba. Penelitian ini menghasilkan tujuh (7) butir soal yang berkualitas yaitu valid, reliabel, daya pembeda dan tingkat kesukaran yang baik. Soal ini mampu menarik minat, memotivasi dan memberikan stimulus kepada subjek uji coba untuk memunculkan kemampuan literasi statistika siswa.

Kata Kunci: literasi statistika, pengembangan soal, PISA, soal statistika.
\end{abstract}

\section{Development of the Statistical Test Instrument PISA Model for practicing students' statistical literacy skills}

\begin{abstract}
The achievement of the mathematics achievement of students in Indonesia is still low, it can be seen from the results of the PISA study in 2015. One of the factors is because students are not trained to solve problems with characteristics such as PISA questions. It takes a development of questions that can provide space for students to practice mathematical literacy, one of which is the ability of statistical literacy. This study aims to develop quality PISA model statistical problems to practice the statistical literacy skills of students. The type of research used was Research and Development with the 4D (Four D) Model. The subject of this research trial was grade VIII B students of SMP Negeri 1 Bintan in the academic year 2018/2019. Data collection instruments used were instruments to measure the validity of questions and test results sheets. The data analysis technique used is the analysis of the data validation of the questions and the results of the trial. This study produced 7 quality items namely valid, reliable, distinguishing features, and a good level of difficulty. This question is able to attract interest and motivate and provide stimulus to test subjects to bring up the statistical literacy skills of students.

Keywords: statistical literacy, development of Test Instrument, PISA, statistical questions.
\end{abstract}

\section{Pendahuluan \\ Program for International Student \\ Assessment (PISA) adalah penelitian ilmiah}


tentang pencapaian siswa tingkat internasional yang diselenggarakan oleh Organisation for Economic Cooperation and Development (OECD) atau organisasi untuk kerjasama ekonomi dan pembangunan (OECD, 2016; Kemdikbud, 2016). Kemampuan siswa yang dinilai dalam studi PISA meliputi literasi matematis, literasi membaca dan literasi sains, dan literasi keuangan.

PISA dilaksanakan setiap 3 tahun sekali sejak tahun 2000 dengan tujuan untuk menilai pencapaian pendidikan siswa yang berusia 15 tahun dalam menguasai pengetahuan dan keterampilan literasi matematis untuk dapat berpartisipasi sebagai warga negara yang konstruktif, terlibat, dan reflektif (OECD, 2018; Stacey, 2011). Literasi matematis yang dimiliki siswa dilihat bagaimana cara siswa menerapkan pengetahuan dan keterampilan matematis dalam masalah kehidupan sehari-hari (Afriansyah, 2016; Muzaki \& Masjudin, 2019; Lestariningsih, Nurhayati, \& Cicinidia, 2020). Sehingga pengetahuan tersebut dapat dirasakan lebih bermanfaat secara langsung oleh siswa.

Pentingnya literasi matematis ini, ternyata belum diikuti dengan hasil pencapaian prestasi siswa di Indonesia (Dewi \& Afriansyah, 2018; Prabawati, Herman, \& Turmudi, 2019). Hal ini berdasarkan hasil studi PISA bidang matematika pada tahun 2018 menunjukkan Indonesia berada diperingkat 72 dari 78 negara yang berpartisipasi (OECD, 2019). Salah satu faktor dari rendahnya hasil studi PISA di Indonesia yaitu siswa kurang terlatih menyelesaikan soal berkarakteristik seperti soal PISA. Hal ini didukung oleh pernyataan dari Wardhani (2011) yang mengungkapkan bahwa salah satu faktor penyebab rendahnya hasil PISA dikarenakan siswa Indonesia pada umumnya kurang terlatih menyelesaikan soal dengan karakteristik seperti soal pada PISA. Siswa terbiasa mengerjakan soal yang sesuai dengan contoh yang diberikan oleh pendidik. Apabila pola soal yang diberikan tidak sama dengan yang diajarkan, siswa tersebut akan mengalami kesulitan.

Kurangnya ketersediaan soal model PISA menjadi salah satu penyebab siswa kurang terlatih dalam menyelesaikan soal PISA. Perkembangan kemampuan literasi matematis siswa rendah jika instrumen penilaian hasil belajar kurang memfasilitasi siswa dalam melatih kemampuan literasinya.

Soal yang dapat melatih kemampuan literasi matematika di antaranya adalah soal model PISA. Soal PISA terdiri dari 4 konten yaitu Shape and Space, Change and Relationship, Quantity, dan Uncertainty and Data. Salah satu dari keempat konten PISA adalah Data. NCTM memasukkan konten "Analisis Data" di salah satu dari lima standar isi yaitu Bilangan dan Operasi Bilangan, Aljabar, Geometri, Data dan Probabilitas, dan Pengukuran (NCTM, 
2000). Di Indonesia, konten Data (data) disebut dengan materi statistika.

Berdasarkan hasil penelitian dari Thirafi (2017) dapat diketahui bahwa tingkat literasi statistik siswa tergolong dalam kategori sangat rendah dimana persentasenya adalah 48,6\%. Sebagian besar siswa mengalami kesulitan dalam mengerjakan soal statistika yang diberikan. Thirafi (2017) menyarankan agar guru menambah intensitas pemberian latihan soal statistika yang ada di kehidupan sehari-hari untuk membiasakan siswa menerapkan kemampuan literasi statistikanya.

Sehubungan dengan permasalahan yang disajikan terlihat jika dibutuhkan suatu pengembangan soal yang mampu memberi ruang bagi siswa untuk lebih melatih kemampuan literasi statistikanya, sehingga penulis tertarik untuk melakukan penelitian dengan judul "Pengembangan Soal Statistika Model Program for International Student Assessment (PISA) untuk Melatih Kemampuan Literasi Statistika Siswa".

Berdasarkan uraian di atas, rumusan masalah pada penelitian ini yaitu bagaimana pengembangan soal statistika model PISA yang berkualitas untuk melatih kemampuan literasi statistika siswa. Sedangkan tujuan penelitian ini yaitu untuk mengembangkan soal statistika model PISA yang berkualitas untuk melatih kemampuan literasi statistika siswa.

\section{Metode}

Jenis penelitian ini merupakan Research and Development (R\&D). Research and Development adalah penelitian yang bertujuan untuk menghasilkan dan menguji keefektifan produk yang dihasilkan (Sugiyono, 2016). Model penelitian yang digunakan adalah model 4D (Four D) yang dikembangkan oleh Thiagarajan (1974). Penulis menggunakan model 4D karena langkah-langkah model pengembangan yang disajikan praktis untuk diterapkan dan sesuai dengan tujuan penelitian. Kegiatan setiap tahapan penelitian pengembangan model 4D seperti yang dijelaskan oleh Mulyatiningsih (2014) adalah sebagai berikut:

\section{A. Tahap Define}

Tahap pendefinisian bertujuan untuk menetapkan dan mendefinisikan kebutuhan-kebutuhan pembelajaran serta mengumpulkan berbagai informasi yang berkaitan dengan produk yang akan dikembangkan. Adapun kegiatan yang dilakukan yaitu analisis awal, analisis siswa, analisis konsep, analisis tugas, dan analisis tujuan pembelajaran.

\section{B. Tahap Design}

Tujuan dari tahap ini adalah untuk merancang bentuk dasar dari soal model PISA. Perancangan bentuk dasar tersebut yaitu penyusunan kisi-kisi soal yang bertujuan untuk merumuskan ruang lingkup dan pencapaian soal serta petunjuk merakit soal. Kisi-kisi disusun berdasarkan indikator kemampuan literasi kuantitatif yang dimodifikasi dari Rafianti \& Setiani (2018) yaitu indikator 
interpretasi, representasi, kalkulasi, asumsi, aplikasi/analisis, dan komunikasi.

\section{Tahap Development}

Tujuan dari tahap ini yaitu menghasilkan Draft Soal yang telah direvisi para ahli dan telah berkualitas berdasarkan analisis hasil uji coba. Tahapan ini merupakan tahap lanjutan untuk menyempurnakan Draft I sebelum menjadi versi final. Kegiatan pada tahap ini yaitu penyusunan soal, penilaian para ahli dan uji coba produk.

\section{Tahap Dissemination}

Setelah uji coba, tahap berikutnya adalah tahap penyebaran. Tujuan dari tahap ini yaitu menyebarluaskan soal statistika model PISA yang berkualitas. Penelitian ini hanya melakukan disseminasi terbatas yaitu menyebarluaskan produk akhir secara terbatas kepada guru matematika di SMPN 1 Bintan.

Adapun prosedur uji coba produk penelitian ini yaitu: 
Cukup. Penggolongan kriteria berdasarkan angka indeks disajikan pada Tabel 1.

Tabel 1.

Pedoman Penilaian Lembar Validasi

\begin{tabular}{|cc|}
\hline Angka Indeks & Kriketia \\
\hline $4,21-5$ & Sangat Baik (SB) \\
\hline $3,41-4,20$ & Baik (B) \\
\hline $2,61-3,40$ & Cukup (C) \\
\hline $1,81-2,60$ & Kurang (K) \\
\hline $1,00-1,80$ & Sangat Kurang (SK) \\
\hline
\end{tabular}

Data hasil uji coba diperoleh dari skor jawaban siswa berdasarkan rubrik penskoran literasi kuantitatif yang kemudian dianalisis berdasarkan pemodelan Rasch dengan bantuan software Winsteps (Sumintono, B., \& Widhiarso, 2014; Purnomo, 2016) untuk menguji validitas, reabilitas, tingkat kesukaran dan daya pembeda.

\section{A. Validitas}

Validitas adalah suatu ukuran yang menunjukkan tingkat kesahihan suatu instrumen. Suatu instrumen pengukuran dikatakan valid apabila mampu mengukur apa yang ingin diukur (Sugiyono, 2016). Kriteria validitas butir soal dan nilai interval dari kriteria tersebut pada pemodelan Rasch dengan bantuan software Winsteps (Sumintono, B., \& Widhiarso, 2014; Purnomo, 2016) disajikan dalam Tabel 2.

Tabel 2.

Kriteria Validitas Butir Soal

\begin{tabular}{cc|}
\hline Interval & Kriteria \\
\hline $0,50<$ MNSQ $<1,5$ & Diterima \\
\hline$-2,0<$ ZSTD $<+2,0$ & Diterima \\
\hline $0,4<$ Pt Mean Cor $<0,85$ & Diterima \\
\hline
\end{tabular}

Hasil pengolahan data hasil uji coba kemampuan literasi statistika siswa menunjukkan setidaknya dua kriteria di atas yang nilainya ada pada interval tersebut, maka butir soal dapat dikatakan valid.

\section{B. Reliabilitas}

Reliabilitas menunjuk pada pengertian konsistensi soal sebagai instrumen tes sehingga intrumen tes tersebut yang dapat dipercaya (Sugiyono, 2016). Soal statistika model PISA dinyatakan reliabel apabila soal tes tersebut minimal memiliki kriteria reliabilitas cukup (minimal 0,67). Kriteria reliabel berdasarkan Rasch Model dengan bantuan software Winsteps (Sumintono, B., \& Widhiarso, 2014; Purnomo, 2016) disajikan dalam Tabel 3.

Tabel 3.

Kriteria Reabilitas Berdasarkan Nilai Item Reliability

\begin{tabular}{|cc|}
\hline Item Reliability & Kriteria \\
\hline$<0,67$ & Lemah \\
\hline $0,67-0,80$ & Cukup \\
\hline $0,81-0,90$ & Bagus \\
\hline $0,91-0,94$ & Bagus Sekali \\
\hline$>0,94$ & Istimewa \\
\hline
\end{tabular}

\section{Tingkat Kesukaran}

Tingkat kesukaran adalah suatu bilangan yang menyatakan tingkat kesukaran suatu butir soal. Menurut Bagiyono (2017), soal yang berkualitas memiliki tingkat kesukaran yang baik yaitu memiliki keseimbangan dalam perbandingan antara butir-butir soal yang mudah, sedang, dan sulit. Tingkat kesukaran butir soal akan dikelompokkan dengan pentunjuk: kelompok butir soal 
mudah, dapat diketahui dari nilai batas bawah yang diperoleh dari rata-rata item logit dari Tabel item measure. Kelompok butir soal sulit, dapat diketahui dari nilai batas atas yang diperoleh dari rata-rata person logit dari Tabel person measure. Sedangkan kelompok butir soal sedang berada diantara batas atas dan batas bawah.

\section{Daya Pembeda}

Daya beda butir soal yaitu kesanggupan soal dalam membedakan kemampuan individu peserta didik. Suatu soal mempunyai daya pembeda yang baik jika butir soal tersebut mampu membedakan antara siswa yang berkemampuan tinggi dengan siswa yang berkemampuan rendah (Bagiyono, 2017). Dengan kata lain, daya pembeda yang baik minimal mampu menggolongkan kemampuan siswa menjadi dua kelompok yaitu tinggi dan rendah. Daya beda dapat diketahui dari nilai separation (Sumintono, B., \& Widhiarso, 2014). Semakin besar nilai separation maka kualitas instrumen akan semakin baik. Pengelompokkan peserta didik dapat dihitung dengan menggunakan rumus sebagai berikut:

$$
H=[4 \times \text { separation }+1] / 3
$$

\section{Hasil dan Pembahasan}

Hasil dari uji coba delapan (8) butir soal yang sudah memenuhi indikator pencapaian kompetensi statistika menghasilkan tujuh (7) butir soal statistika model PISA yang berkualitas yaitu valid, reliabel, daya pembeda dan tingkat kesukaran yang baik untuk melatih kemampuan literasi statistika siswa. Data dari hasil dan pembahasan setiap tahapan prosedur penelitian dan pengembangan yang dilakukan adalah sebagai berikut:

\section{A. Tahap Define}

Analisis awal dilakukan dengan mewawancarai guru matematika di SMPN 1 Bintan. Informasi yang diperoleh yaitu sekolah tersebut menggunakan kurikulum 2013, materi yang telah diterima siswa kelas VIII di semester ini yaitu Teorema Pythagoras, Lingkaran, Bangun Ruang Sisi Datar, Statistika, dan Peluang, sedangkan untuk soal, sering memberi soal rutin yang ada di buku paket sehingga siswa jarang mengerjakan soal model PISA.

Analisis siswa juga dilakukan dari hasil wawancara dari guru matematika dan diketahuilah bahwa kemampuan matematika siswa SMPN 1 Bintan kelas VIII disetiap kelas heterogen. Ada yang berkemampuan kurang, sedang dan tinggi. Sedangkan terhadap pencapaian kemampuan statistikanya, rata-rata tingkat kemampuan siswanya berkategori sedang.

Analisis konsep dilakukan dengan cara membaca referensi dari framework PISA (OECD, 2018) dan Buku Siswa Matematika kelas VIII SMP/MTs (Kemdikbud, 2017). Dari cara tersebut ditemukan kesamaan topik tentang konten Data atau Statistika yaitu pada Variabilitas data dan deskripsi dengan distribusi data, penyebaran data dan pemusatan data. Dari kesamaan hasil analisis konsep ini mengharuskan sepaket 
soal yang penulis kembangkan memenuhi semua topik yang bersesuaian antara referensi framework PISA dan Buku Siswa Matematika kelas VIII SMP/MTs yaitu distribusi data, mean, median, modus, dan penyebaran data.

Analisis tugas yang dilakukan yaitu mengidentifikasi Kompetensi Inti (KI) dan Kompetensi Dasar (KD) terkait materi statistika. KI dan KD Materi Statistika. Sedangkan analisis tujuan pembelajaran yaitu mengkonversi tujuan dari analisis konsep dan analisis tugas menjadi tujuan pembelajaran untuk menentukan indikator pencapaian kompetensi. Adapun tujuantujuan pembelajaran pada materi statistika yaitu: (1) Menganalisis data dari distribusi yang diketahui; (2) Menentukan nilai ratarata (mean) dari suatu data; Menentukan median dan modus suatu data; dan (4) Menentukan ukuran penyebaran data.

\section{B. Tahap Design}

Tahap ini menghasilkan 8 butir kisi-kisi soal yang sesuai dengan komponen utama PISA dan indikator kemampuan literasi statistika siswa disertai dengan judul soal secara umum.

\section{Tahap Development}

Kegiatan pada tahap ini adalah penyusunan soal, penilaian para ahli dan uji coba produk. Penyusunan soal menghasilkan rancangan awal berupa Draft I yang terdiri dari identitas paket soal, 8 petunjuk pengerjaaan soal, dan 8 soal PISA. Tampilan 3 soal dari Draft I yang dikembangkan disajikan pada Tabel 4.
Tabel 4.

Draft I

\begin{tabular}{ll}
\hline $\mathrm{N}$ & Draft I \\
$\mathrm{O}$ & \\
\hline 1 Suatu pagi Pak Darno memberikan ulangan
\end{tabular}

1 Suatu pagi Pak Darno memberikan ulangan matematika di kelas VII A yang berjumlah 30 orang. Setelah selesai, Pak Darno mengumumkan bahwa nilai ulangan tertinggi diperoleh Fionna dan nilai terendah diperoleh Jecky dengan selisih 37. Pak Darno juga mengumumkan bahwa nilai rata-rata ulangan matematika di VII A adalah 80,8 sedangkan jika nilai Fionna dan Jecky tidak diikutsertakan, rata-rata ulangan menjadi 80,75 . Carilah nilai terendah dari 30 orang siswa tersebut!

2 Gambar berikut menunjukkan harga sepatu yang terdapat di Toko Adil Makmur.

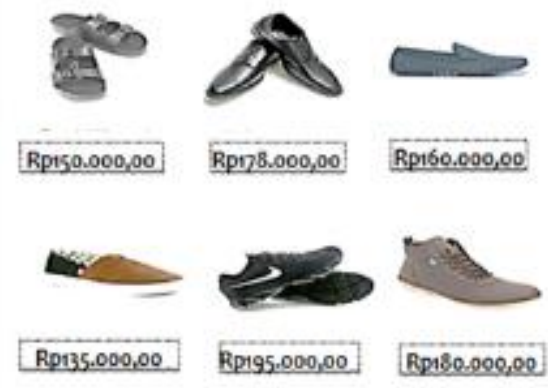

Pemilik toko mengatakan bahwa median dari harga sepatu adalah Rp160.000,00. Apakah pernyataan dari Pemilik toko benar? Jika salah coba kamu betulkan pernyataan dari pemilik toko tersebut!

3 Elmen berolahrga setiap 2 hari sekali. Jaeger berolahraga setiap 3 hari sekali. Willy berolahraga 4 hari sekali. Hendy berolahraga setiap harinya. Jika keempat siswa tersebut memulai berolahraga bersamaan dihari selasa pada tanggal 1 Mei 2019, maka pada hari apakah keempat siswa tersebut paling sering berolahraga dalam 15 hari kedepan?

Validasi ahli merupakan teknik untuk memperoleh masukan dan penilaian soal yang dikembangkan. Validatornya yaitu salah satu dosen di Sekolah Tinggi Teknologi Informatika Indonesia sekaligus 
guru matematika di SMPN 1 Bintan dan salah satu guru matematika di SMPN 15 Tanjungpinang. Validator diminta untuk menvalidasi Draft I yang terdiri dari 8 soal berdasarkan validasi isi, konstruk, dan bahasa soal. Hasil analisis validator terhadap soal statistika model PISA yang dikembangkan ditampilkan pada Tabel 5.

Tabel 5.

Hasil Analisis Validator

\begin{tabular}{|c|c|c|}
\hline Aspek & Validator & Kriteria \\
\hline & 1 & \\
\hline Isi & 3,80 & Baik \\
\hline Konstruk & 3,71 & Baik \\
\hline Bahasa & 3,75 & Baik \\
\hline
\end{tabular}

Hasil analisis validator menunjukkan bahwa soal yang ditelaah oleh kedua validator telah mendukung validitas soal dengan kriteria baik. Dapat dikatakan bahwa soal Draft I dikatakan valid dan soal Draft I direvisi berdasarkan saran atau masukan dari validator yang disajikan pada Tabel 6.

Tabel 6.

Revisi Soal Statistika Model PISA

\begin{tabular}{|c|c|c|}
\hline $\begin{array}{l}N \\
0\end{array}$ & Sebelum Revisi & Sesudah Revisi \\
\hline 1 & $\begin{array}{l}\text { Carilah nilai } \\
\text { terendah dari } 30 \\
\text { orang siswa } \\
\text { tersebut! (saran } \\
\text { validator yaitu } \\
\text { perbaiki redaksi } \\
\text { pertanyaan soal agar } \\
\text { lebih kontekstual } \\
\text { dan megajak siswa } \\
\text { berfikir) }\end{array}$ & $\begin{array}{l}\text { Jecky ingin tahu } \\
\text { berapa nilai yang } \\
\text { diperolehnya tetapi } \\
\text { Pak Darno tidak } \\
\text { memberitahunya. } \\
\text { Ayo cari tahu nilai } \\
\text { ulangan yang } \\
\text { diperoleh Jecky pagi } \\
\text { ini! }\end{array}$ \\
\hline 2 & $\begin{array}{l}\text { saran validator yaitu } \\
\text { berikan soal ke siswa } \\
\text { yang menuntut siswa } \\
\text { mengerjakan dengan } \\
\text { langkah-langkah } \\
\text { sistematis, jangan }\end{array}$ & $\begin{array}{l}\text { Redaksi dan gambar } \\
\text { diubah }\end{array}$ \\
\hline
\end{tabular}

\begin{tabular}{|lll|}
\hline \multicolumn{3}{|c|}{ terlalu mudah } \\
\hline 3 & Saran validator yaitu & Ditambah gambar \\
lebih dikembangkan & dan tambah redaksi \\
soalnya & soal
\end{tabular}

Setelah draft I direvisi berdasarkan masukan dan penilaian validator maka tersusun Draft II seperti pada Tabel 7.

Tabel 7.

Draft II

\begin{tabular}{ll}
\hline $\mathbf{N}$ & Draft II \\
\hline o & \\
\hline 1 Suatu pagi Pak Darno memberikan ulangan \\
matematika di kelas VII A yang berjumlah 30 \\
orang. Setelah selesai, Pak Darno \\
mengumumkan bahwa nilai ulangan \\
tertinggi diperoleh Fionna dan nilai \\
terendah diperoleh Jecky dengan selisih 37. \\
Pak Darno juga mengumumkan bahwa nilai \\
rata-rata ulangan matematika di VII A \\
adalah 80,8 sedangkan jika nilai Fionna dan \\
Jecky tidak diikutsertakan, rata-rata ulangan \\
menjadi 80,75. Jecky ingin tahu berapa nilai \\
yang diperolehnya tetapi Pak Darno tidak \\
memberitahunya. Ayo cari tahu nilai \\
ulangan yang diperoleh Jecky pagi ini
\end{tabular}

2 Gambar berikut menunjukkan harga sepatu yang terdapat di Toko Adil Makmur.

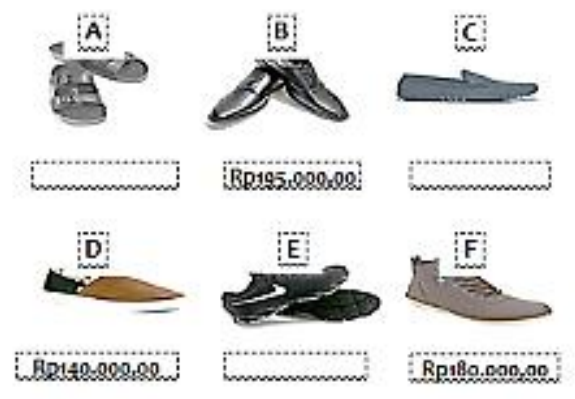

Harga sepatu A yaitu 5/6 dari harga sepatu F. Harga sepatu C yaitu $4 / 5$ dari harga sepatu B. Harga sepatu E yaitu 8/7 dari harga sepatu D.

Pemilik toko mengatakan bahwa pertengahan harga (median) dari sepatu yang dijualnya adalah Rp150.000,00. Apakah pernyataan dari Pemilik toko benar? Jika salah coba kalian betulkan pernyataan dari pemilik toko tersebut! 


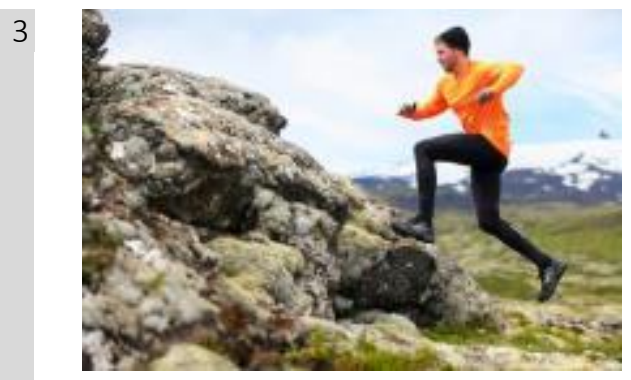

Elmen, Jaeger, Willy, dan Hendy adalah siswa yang suka berolahraga pada pagi hari. Elmen berolahrga setiap 2 hari sekali. Jaeger berolahraga setiap 3 hari sekali. Willy berolahraga 4 hari sekali. Hendy berolahraga setiap harinya. Jika keempat siswa tersebut memulai berolahraga bersamaan dihari selasa pada tanggal 1 Mei 2019, maka pada hari apakah keempat siswa tersebut paling sering berolahraga dalam 15 hari kedepan? Jelaskan!

Uji coba produk atau uji coba lapangan dilakukan untuk memperoleh data kualitas butir soal statistika model PISA yang dikembangkan. Draft II diuji cobakan pada siswa SMPN 1 Bintan di kelas VIII B dengan rincian 15 siswa mengerjakan 8 butir soal matematika model PISA yang telah dibuat. Data hasil uji coba lapangan kemudian dilakukan dilakukan uji validitas, rebialitas, tingkat kesukaran dan daya pembeda menggunakan Rasch Model dengan bantuan softwere Winsteps.

Rekapitulasi analisis kualitas butir soal statistika model PISA untuk melatih kemampuan literasi statistika siswa disajikan pada Tabel 8.

Tabel 8.

\begin{tabular}{|c|c|c|c|c|}
\hline $\begin{array}{l}\text { No. } \\
\text { Soal }\end{array}$ & Validitas & Reabilitas & $\begin{array}{c}\text { Tingkat } \\
\text { Kesukaran }\end{array}$ & $\begin{array}{c}\text { Daya } \\
\text { Pembeda } \\
\end{array}$ \\
\hline 1 & Valid & Bagus & Baik & Baik \\
\hline 2 & Invalid & & & \\
\hline 3 & Valid & & & \\
\hline 4 & Valid & & & \\
\hline 5 & Valid & & & \\
\hline 6 & Valid & & & \\
\hline
\end{tabular}

\begin{tabular}{|cc}
\hline 7 & Valid \\
\hline 8 & Valid \\
\hline
\end{tabular}

Dari keempat uji instrumen tes yang berkualitas dapat diketahui bahwa dari 8 soal yang diuji cobakan hanya 1 soal yang tidak berkualitas yaitu soal nomor 2. Soal nomor 2 tidak memenuhi satu persyaratan instrumen tes yang berkualitas yaitu validitas. Sedangkan 7 soal yang lainya bisa diterima sebagai soal statistika model PISA yang berkualitas untuk melatih kemampuan literasi statistika siswa.

\section{Tahap Dissemination}

Kegiatan yang dilakukan pada tahap ini yaitu menyebarluaskan Soal statistika model PISA yang berkualitas untuk melatih kemampuan literasi statistika siswa. Pada pelaksanaan tahap ini hanya dilakukan disseminasi terbatas dengan memberikan produk akhir berbentuk softfile dan hardfile kepada guru matematika di SMPN 1 Bintan.

Pengembangan soal matematika model PISA konten statistika ini telah melalui semua tahap dari desain model 4D. Model 4D dimulai dari tahap define (pendefenisian), design (perancangan), develop (pengembangan), dan disseminate (penyebaran) sehingga menghasilkan sebuah produk yang berkualitas. Produk yang dimaksud ialah soal statistika model PISA untuk melatih kemampuan literasi statistika siswa.

Berdasarkan hasil yang diperoleh dari tahap define (pendefenisian), design (perancangan), develop (pengembangan), penilaian para ahli serta uji coba lapangan menunjukkan bahwa soal model PISA 
konten statistika yang dikembangkan kebanyakan berhasil mencapai kriteria berkualitas. Soal model PISA yang dikembangkan ini dikatakan berkualitas karena soal tersebut valid, reliabel, daya pembeda dan tingkat kesukaran yang baik.

Validitas uji coba soal model PISA konten statistika yang terdiri dari 8 soal menghasilkan 1 soal yang tidak valid dan tidak dapat digunakan yaitu soal nomor 2 di paket 1 sedangkan 7 soal lainnya berkategori valid. Faktor yang mempengaruhi soal tersebut valid dari uji coba lapangan yaitu soal yang peneliti kembangkan sudah melalui aktivitas analisis konsep, tugas, dan tujuan pembelajaran serta validasi isi oleh validator dengan pencapaian kriteria baik. Jadi, soal yang penulis kembangkan sangat wajar jika bisa digunakan untuk mengukur kemampuan literasi statistika siswa. Hal ini sesuai dengan pendapat Arifin (2016) yaitu jika suatu tes dapat mencapai tujuan tertentu, maka tes itu valid untuk tujuan tertentu.

Reliabilitas soal model PISA yang penulis kembangkan secara umum dinyatakan reliabel dengan kategori bagus. Hal ini bermakna soal model PISA konten statistika yang telah dikembangkan dapat dipercaya sebagai instrumen tes dan mampu memberikan hasil yang sama apabila instrumen tes ini dilakukan pada subjek, tempat maupun kondisi yang berbeda. Faktor yang mempengaruhi reliabilitas butir soal yang penulis kembangkan yaitu banyaknya soal yang valid dan objektifitas. Jika butir soal mampu mempresentasikan aspek yang ingin diukur, maka soal akan reliabel. Sedangkan objektifitas di sini ditunjukkan pada hasil skor tes yang sama pada siswa yang berkemampuan sama antara yang satu dengan yang lain. Jika siswa memiliki tingkat kemampuan yang sama, maka akan memperoleh hasil tes yang sama ketika mengerjakan tes yang sama (Arifin, 2016).

Hasil uji coba tingkat kesukaran butir soal menunjukkan 4 soal berkategori sedang, 2 soal berkategori sulit, dan 2 soal berkategori mudah yang menunjukkan soal yang diujikan memiliki ketiga macam tingkat kesukaran yaitu sulit, sedang, dan mudah. Hal ini dapat disimpulkan bahwa soal yang penulis uji cobakan berkategori baik. Soal dengan kategori sulit menunjukkan bahwa hanya sebagian kecil subjek uji coba yang mengerjakannya dan soal yang sulit membutuhkan pemahaman yang dalam. Soal dengan kategori sedang menunjukkan bahwa soal yang diujicobakan tergolong sedang untuk subjek uji coba dengan kemampuan tinggi dan sedang. Soal dengan kategori mudah menunjukkan bahwa soal tergolong mudah dikerjakan untuk subjek uji coba memiliki kemampuan tinggi, sedang, maupun rendah.

Daya pembeda soal model PISA konten statistika yang penulis kembangkan secara umum menunjukkan soal tersebut sanggup menggolongkan kemampuan siswa uji coba menjadi 4 kelompok yaitu siswa berkemampuan tinggi, di atas rata- 
rata, di bawah rata-rata, dan rendah. Dengan demikian daya pembeda soal statistika model PISA ini memiliki kualitas yang baik sebagai instrumen tes.

Berdasarkan penjelasan di atas diketahui bahwa terdapat soal uji coba yang tidak berkualitas. Soal yang tidak berkualitas tidak memenuhi karakteristik alat ukur yang baik (Arifin, 2016) sehingga untuk menghasilkan Draft III yang sesuai dengan kriteria instrumen tes yang berkualitas maka butir soal tersebut tidak digunakan sebagai soal model PISA. Butir soal yang dibuang yaitu soal nomor 2 . Adapun butir soal lainnya dapat diterima sebagai instrumen tes yang berkualitas dengan jumlah 7 soal. Dengan demikian, soal tes dari Draft III yang dihasilkan pada penilitian ini berjumlah tujuh (7) soal uraian dengan alokasi waktu 2×40 menit.

\section{Penutup}

Berdasarkan hasil penelitian dapat disimpulkan bahwa penelitian ini menghasilkan tujuh (7) butir soal yang valid, reliabel, daya pembeda, dan tingkat kesukaran yang baik serta dapat diterima sebagai soal statistika model PISA yang berkualitas untuk melatih kemampuan literasi statistika siswa.

\section{UCAPAN TERIMA KASIH}

Penulis mengucapkan terimakasih kepada pihak SMPN 1 Bintan yang telah mengizinkan penulis penelitian, kepada Ibu Nelwati, M.Pd. dan Ibu Dra. Ultra Falentina yang telah memvalidasi produk penulis, dan juga kepada siswa kelas VIII B yang telah bersedia menjadi subjek uji coba penelitian ini.

\section{DAFTAR PUSTAKA}

Afriansyah, E. A. (2016). Enhancing Mathematical Problem Posing via Realistic Approach. International Seminar on Mathematics. Science, and Computer Science Education MSCEIS.

Arifin, Z. (2016). Evaluasi pembelajaran. Bandung: Remaja Rosdakarya.

Bagiyono. (2017). Analisis Tingkat Kesukaran dan Daya Pembeda Sial Ujian Pelatihan Radiografi Tingkat 1. Widyanuklida, 16(1), 1-12.

Dewi, S. S. S., \& Afriansyah, E. A. (2018). Kemampuan Komunikasi Matematis Siswa Melalui Pembelajaran CTL. JIPMat, 3(2), 145-155.

Kemdikbud. (2016). Hasil survei PISA: peningkatan capaian indonesia termasuk empat besar.

Kemdikbud. (2017). Matematika SMP/MTS kelas VIII semester 2. Jakarta: Kementerian Pendidikan dan Kebudayaan.

Lestariningsih, L., Nurhayati, E., \& Cicinidia, C. (2020). Jenis Proses Berpikir Peserta Didik dalam Menyelesaikan Soal Literasi Matematis. Mosharafa: Jurnal Pendidikan Matematika, 9(1), 83-94.

Mulyatiningsih, E. (2014). Riset terapan bidang pendidikan \& teknik. Yogyakarta: UNY Press.

Muzaki, A., \& Masjudin, M. (2019). Analisis Kemampuan Literasi Matematis Siswa. Mosharafa: Jurnal Pendidikan Matematika, 8(3), 493-502. 
NCTM. (2000). Principles and standars for scool matematics. United States of Amerika: The National Council of Teachers of Mathematics, Inc.

OECD. (2019). PISA 2018 results.

OECD. (2018). PISA 2015 draft mathematics framework.

Prabawati, M. N., Herman, T., \& Turmudi, T. (2019). Pengembangan Lembar Kerja Siswa Berbasis Masalah dengan Strategi Heuristic untuk Meningkatkan Kemampuan Literasi Matematis. Mosharafa: Jurnal Pendidikan Matematika, 8(1), 37-48.

Purnomo, S. (2016). Pengembangan Soal Matematika Model Pisa Konten Space And Shape Untuk Mengetahui Level Kemampuan Berpikir Tingkat Tinggi Berdasarkan Analisis Model Rasch. Tesis Magister Thesis tersedia di Digital Ripository Universitas Jember.

Rafianti, I., \& Setiani, Y. (2018). Profil kemampuan literasi kuantitatif calon guru matematika. Jurnal Penelitian dan Pembelajaran Matematika, 11(1), 63-74.

Riduwan. (2015). Skala pengukuran variabel-variabel penelitian. Jawa Barat: Alfabeta.

Stacey, K. (2011). The PISA view of mathematical literacy in Indonesia. Journal on Mathematics Education (IndoMS-JME), 2(2), 95-126.

Sugiyono. (2016). Metode penelitian kuantitatif, kualitatif, dan R\&D. Bandung: Alfabeta.

Sumintono, B., \& Widhiarso, W. (n.d.). Aplikasi pemodelan rasch pada assessment pendidikan. Cimahi: Trim Komunikata.

Thirafi, G. (2017). Analisis tingkat literasi statistik pada siswa kelas IX MTs. Al- aziziyah Putra Gunung Sari tahun pelajaran 2016/2017. Artikel Skripsi tersedia di Docplayer Universitas Mataram.

Wardhani, S. \& R. (2011). Instrumen penilaian hasil belajar matematika SMP: belajar dari PISA dan TIMSS. Yogyakarta: PPPPTK.

\section{Riwayat Hidup PenUlis}

Nielda Junika, S.Pd.

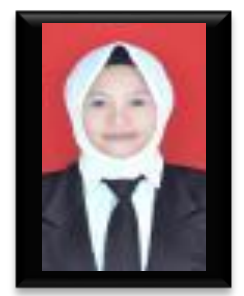

Lahir di Karimun, 14 Juni 1997. Studi S1 Pendidikan Matematika di Universitas Maritim Raja Ali Haji (UMRAH), Tanjungpinang. Lulus tahun 2019.

\section{Dr. Nur Izzati, S.Pd., M.Si.}

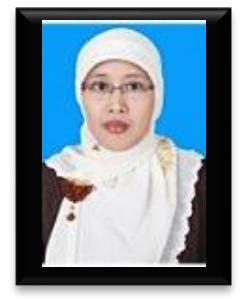

Lahir di Sitalang tanggal 25 Maret 1970. Staf pengajar program studi pendidikan matematika di Universitas Maritim Raja Ali Haji. Studi S1 Pendidikan Matematika di Universitas Bung Hatta, Padang. Tahun lulus 1996. Studi S2 Matematika Terapan di Institut Teknologi Bandung. Tahun lulus 2007. Studi S3 Pendidikan Matematika di Universitas Pendidikan Indonesia. Tahun lulus 2012.

\section{Dra. Linda Rosmeri Tambunan, M.Si.}

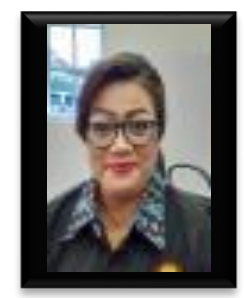

Lahir di Medan tanggal 2 Oktober 1966. Staf pengajar program studi pendidikan matematika di Universitas Maritim Raja Ali Haji. Menyelesaikan Studi S1 Matematika di Universitas Sisingamangaraja. Tahun lulus 1989. Studi S2 Matematika di Universitas Sumatra Utara. Tahun lulus 2006. 